UDC 613.95: 616-006.44: 614.876

DOI: $10.21668 /$ health.risk/2019.1.03.eng

\title{
THE RISK OF ONCOHEMATOLOGICAL PATHOLOGY IN CHILDREN OF WORKERS EMPLOYED AT RADIATION HAZARDOUS PRODUCTION
}

\author{
S.F. Sosnina, N.R. Kabirova, M.E. Sokolnikov, P.V. Okatenko \\ The Southern Urals Biophysics Institute of the RF Federal Medical and Biological Agency, \\ 19 Ozerskoe drive, Ozersk, 456780, Russian Federation
}

Preconceptive irradiation is considered to be a potential risk factor that can cause hemolymphoblastosis in children conceived and borne by irradiated parents. A population cohort that comprises workers employed at "Mayak" Production Association (Mayak PA), the first nuclear cycle enterprise, is a unique sampling to calculate a carcinogenic risk in their children.

Our research goal was to assess risk of hemolymphoblastosis among children conceived and borne by workers employed at Mayak PA with individual preconceptive accumulated absorbed dozes.

Data and methods. We performed retrospective research as per "case-control" study among all the people living in the city of Ozersk located near Mayak PA. Hemolymphoblastosis diagnosed in people younger than 25 in 1949-2009 (81 people) were considered to be "cases"; "controls were chosen taking into account sex, birth date, and parents' age when a child was borne (324 people). We calculated odds ratio and excessive relative risk per external gamma-radiation dose unit (ERR/Gy) with $95 \%$ confidence interval; to do that, we applied PEGAN program module of EPICURE software.

Results. Acute leukemia prevailed in the structure of hemolymphoblastosis, acute lymphatic leukemia occupying the first place. We didn't reveal any statistic correlation between a factor related to parents' preconceptive irradiation and oncohematologic pathologies in their offspring: overall, odds relation was equal to $0.76(0.46-1.26)$. As we analyzed "dose - effect" correlation, we didn't reveal any statistically significant increase in morbidity with hemolymphoblastosis depending on a dose of irradiation accumulated by their parents. ERR/Gy quotients were insignificant both for a dose accumulated by a mother and that accumulated by a father. Non-parametric analysis taking into account dose categories didn't reveal any elevated risks either.

Conclusion. We didn't detect any dose dependence between long-term preconceptive external gamma-irradiation accumulated by parents and risks of hemolymphoblastosis in their children. However, a relatively insignificant number of hemolymphoblastosis cases among children younger than 25 imposes certain limitations on validity of our conclusions. Susceptibility to neoplasms in children and manifestation of the effect as a solid carcinoma at older ages are rather probable and it means that further observation and research is required.

Key words: preconceptive radiation exposure of workers, children, dose dependence, risk assessment, malignant neoplasms in lymphoid and blood-making tissues.

Multiple experimental research considers preconception irradiation as a risk factor that can cause genetic instability, changes in DNA polymorphism $[1,2]$, and offspring susceptibility to neoplastic processes [3-5]. Several works dwell on cytogenetic effects as oncologic diseases predictors and on their probable trans-generational transfer among irradiated people [6-9]. But still, epidemiologic assessment of effects produced by preconception irradiation is rather controversial, and there are no common conclusions on peculiarities and regularities which carcinogenic processes have in offspring of people who were exposed to ionizing irradiation $[10,11]$.

Malignant neoplasms (MN) in lymphoid and blood-making tissues are the most widely spread oncologic pathology among children $[12,13]$. A lot of researchers have had great interest in a probable cause-and-effect relationship between parents being exposed to preconception irradiation and hemolymphoblastosis in their children. In 90ties last century several works were published; they focused on testing a so called "Gardner hypothesis" [14] that stated the following: irradiation received by fathers be-

(C) Sosnina S.F., Kabirova N.R., Sokolnikov M.E., Okatenko P.V., 2019

Svetlana F. Sosnina - Candidate of Medicine, Researcher at Radiation Epidemiology Laboratory (e-mail: sosnina@subi.su; tel: +7 (351) 307-66-27; ORCID: https://orcid.org/0000-0003-1553-0963).

Nailya R. Kabirova - Assistance Manager to the Head of Radiation Epidemiology Laboratory (e-mail: kabirova@subi.su; tel: +7 (351) 307-30-76; ORCID: https://orcid.org/0000-0001-7724-6103).

Mikhail E. Sokolnikov - Doctor of Medicine, Head of Epidemiology Department (e-mail: sokolnikov@subi.su; tel: +7 (351) 307-16-52; ORCID: https://orcid.org/0000-0001-9492-4316).

Pavel V. Okatenko - Head of the Group on Computational Hardware and Software, Radiation Epidemiology Laboratory (e-mail: okatenko@subi.su; tel: +7 (351) 307-69-03; ORCID: https://orcid.org/0000-0002-8260-1808). 
fore conception could cause leukemia and nonHodgkin's lymphoma in their children. A correlation between parents' preconception irradiation and leucosis in their children wasn't confirmed in most of them $[15,16]$ or evidences weren't convincing enough due to an insignificant number of oncohematological cases [17, 18]. Controversial results obtained in assessing effects produced by parents' irradiation and related risks of neoplastic processes in their children are still inducing scientific disputes [11, 19-21].

"Mayak" production association (Mayak PA) is the first enterprise in the country that dealt with nuclear production; it was put into operation in 1948. This association includes radiochemical, reactor, and plutonium production as well as several auxiliary divisions. During several first years of Mayak PA operations its personnel might have been exposed to long-term external gamma-irradiation and internal alphairradiation by incorporated plutonium-239 in significant doses; and we should note that a quarter of all workers employed at Mayak PA back then were women in their reproductive age. Given that, a cohort made up of workers employed at Mayak PA is one of the most representative groups in the world to assess effects produced by parents' irradiation, including analysis of oncohematological pathology in their children.

Our research goal was to assess risks of $\mathrm{MN}$ in lymphoid and blood-making tissues among children born by personnel employed at Mayak PA applying total absorbed individual preconception doses.

Data and methods. We conducted a retrospective examination based on registers created and supported in the Laboratory for Radiation Epidemiology at the Southern Urals Biophysics Institute:

- Register with entries on personnel employed at Mayak PA in 1948-2015 including 36,036 people who worked at the main and auxiliary plants of the enterprise; this register provided data on parents' occupational histories;

- Cancer Register that contains data on more than 15,000 cancer cases which have been diagnosed since 1948 among people living in Ozersk, a closed town located near Mayak PA;

- Children Register that contains data on 90,835 people who were born in 1934-2009 in
Ozersk or came to this town in their childhood and spent not less than 1 year in it.

We applied a "case - control study in a cohort" where a "case" was a patient younger than 25 who was suffering from hemolymphoblastosis and a "control" was a person of the same age without such a diagnosis. "Cases" group included all patients with hemolymphoblastosis registered in Ozersk from 1949 to 2009 who were younger than 25 (81 children overall, 49 boys and 32 girls). "Control" group was made up with a comparable pair method as we selected four controls from Children Register for each child with hemolymphoblastosis so that they matched in sex, birth year, and age of parents at the moment of childbirth. Groups were formed among all the children population in Ozersk and it allowed to level off other probable disturbing factors, for example, possible technogenic impacts exerted on people living in the town by its close proximity to Mayak PA. All the selected children were provided with medical services of the same quality and quite similar nutrition in children facilities located in the closed town. As a result, "Control" group consisted of 324 children without any oncologic diseases (196 boys and 128 girls).

Having formed the groups, we detected whether parents had been exposed to preconception irradiation and if yes than what doses they had been exposed to; to do that, we took data from the Mayak PA Personnel Register, registers with data on people who might have been irradiated, for example, liquidators of the emergency that happened at the enterprise in 1957, Chernobyl liquidators, people who had lived on the Eastern Urals radioactive track territory, people employed at construction organizations or military personnel who might have been exposed to radiation before their children were conceived. Data on individual doses of external gamma-irradiation accumulated by personnel employed at Mayak PA were provided by the Radiation Safety Service of the enterprise from the "Mayak PA Personnel Dosimetric System2008" [22, 23].

The structure of $\mathrm{MN}$ in lymphoid and blood-making tissues is given according to the ICD-9 and ICD-10 that were valid during the examined period $[24,25]$. 
We applied the following statistical analysis techniques in our research:

- frequencies comparison with $\chi^{2}$ criterion and Fisher's exact test, discrepancies were considered to be authentic at $\mathrm{p}<0.05$;

- odds ratio (OR) calculation with $95 \%$ confidence interval $(\mathrm{CI})$;

- calculation of excess relative risk (ERR) per a unit of external gamma-irradiation dose with $95 \%$ confidence interval; it was performed in PECAN software module of EPICURE software package [26]. Data in a table that showed person-years were distributed as per sex, birth date, $\mathrm{MN}$ nosology, and a date when a $\mathrm{MN}$ was diagnosed. We took into account total preconception doses of external gamma-irradiation received by mothers and fathers on an overall body and separately on the gonads. Individual doses were divided into $250 \mathrm{mGy}$ intervals and an average dose was calculated for each interval. Morbidity with hemolymphoblastosis among children that was detected without any exposure to radiation was considered to be a background level taking into account discrepancies related to an age at which a MN was diagnosed, sex, or age. P-test values for statistical significance were calculated with maximum likelihood techniques, and discrepancies were considered to be statistically significant at $\mathrm{p}<0.05$.

Groups characteristics taking into account preconception irradiation parents had been exposed to at their workplaces is given in Table 1 .

Each group was divided into two subgroups: children born by parents who had accumulated preconception irradiation doses and children born by parents who had never been exposed to any occupational irradiation before they conceived a child. A share of children born by irradiated parents was lower in "Cases" group than among children without hemolymphoblastosis as $35.8 \%$ (29 children) in "cases" group were born in families where parents had accumulated preconception irradiation doses; as for the group that included children without any on- cohematological pathology, 42.3\% (137 children) were born by parents who had been exposed to occupational irradiation before conception.

Workers who had contacted ionizing radiation sources at their workplaces before conception might have been exposed to combined irradiation (external gamma- and internal alpha-irradiation). Most parents in the compared groups were employed at radiochemical and reactor productions of Mayak PA. We didn't analyze any relationship between $\mathrm{MN}$ in lymphoid and blood-making tissues in children and parents' doses of internal irradiation by incorporated plutonium-239 due to a rather insignificant number of people who had undergone monitoring of internal alpha-irradiation accumulated in their bodies.

Results and discussion. Over 60-yearlong examination period (1949-2009) $\mathrm{MN}$ in lymphoid and blood-making tissues were diagnosed in 81 children, and more frequently in boys ( 49 people or $60.5 \%$ ). Prevalence of males among patients with hemolymphoblastosis (sex ratio is $1.53: 1$ ) is in line with regional, national, and world statistics [13, 27, 28]. The highest number of oncohematological pathology among children were registered in time periods from 1980 to 1989 and from 1990 to 1999 (18 and 19 cases respectively). Average age at which hemoblastosis occurred among boys was equal to 11.5; among girls, 9.5. The structure of $\mathrm{MN}$ in lymphoid and blood-making tissues among overall children population living in Ozersk over 60 years is given on Figure 1.

Acute leukemia prevailed among all the $\mathrm{MN}$ in lymphoid and blood-making tissues with 45 cases $(55.6 \%)$ of which 23 cases or $51.1 \%$ belonged to acute lympholeucosis and it corresponds to literature data [13, 27, 28]. Myeloid leukemia accounted for $26.7 \%$ (12 cases) among all acute leukemia cases. Monocytic leukemia was registered only once, in a 5-year old boy born by a father who had been employed at reactor production and exposed to

Table 1

Group characteristics

\begin{tabular}{|c|c|c|c|c|c|c|c|c|c|}
\hline \multirow{2}{*}{ Group } & \multicolumn{3}{|c|}{ Number of children in a group } & \multicolumn{3}{|c|}{ Born by irradiated parents } & \multicolumn{3}{|c|}{ Born by non-exposed parents } \\
\hline & Total & Boys & Girls & Total & Boys & Girls & Total & Boys & Girls \\
\hline "Cases" & 81 & 49 & 32 & 29 & 19 & 10 & 52 & 30 & 22 \\
\hline "Controls" & 324 & 196 & 128 & 137 & 86 & 51 & 187 & 110 & 77 \\
\hline
\end{tabular}




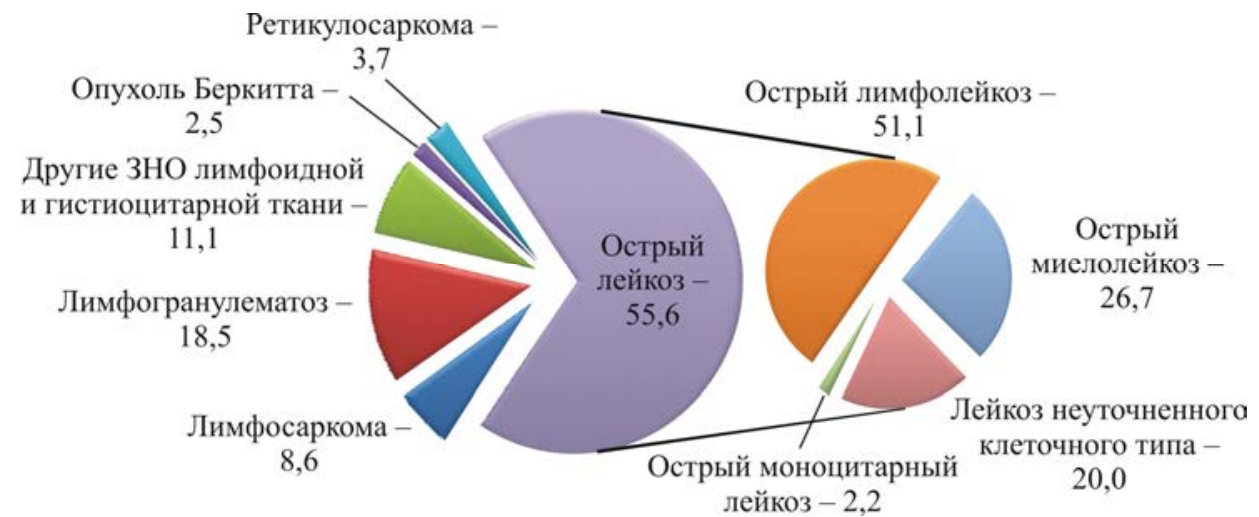

Figure1. Hemolymphoblastosis among children in Ozersk.

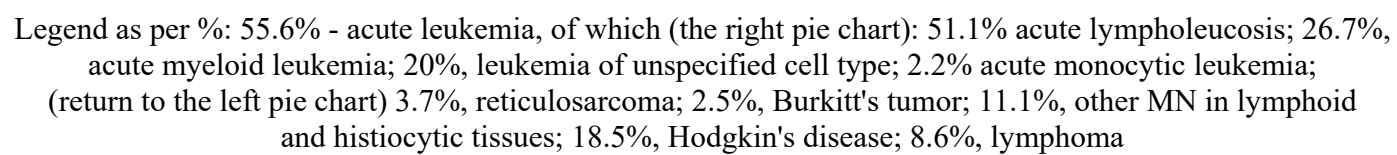

total preconception external gamma-irradiation on his gonads in a dose equal to $210 \mathrm{mGy}$.

Acute leukemia of unspecified cell type was detected in 9 children and it accounted for one fifth of all leukemia cases in children. Most of these unspecified leukemias were diagnosed in 1960-1980; back then it was next to impossible to identify an acute leukemia subtype due to absence of histochemical, immunological, and cytogenetic research techniques.

The second place among all hemolymphoblastosis belongs to Hodgkin's disease (18.5\% or 15 cases). Average age at which the disease became apparent amounted to 16.2, without any gender discrepancies. Two Burkitt's tumors were registered among diffused nonHodgkin's lymphomas, in a 8-year-old girl and 21-year-old boy, both born by parents who hadn't been exposed to any preconception irradiation. "Other malignant neoplasms in lymphoid and histiocytic tissues" category included histiocytic lymphomas and malignant histiocytosis; these diseases accounted for $11.1 \%$ (9 cases) of all hemolymphoblastosis among children living in the closed town.

Structure of hemolymphoblastosis among children born by parents exposed to occupational preconception irradiation is very similar to that described above. Acute leukemia prevailed $(62.1 \%$ or 18 cases $)$; lymphoblastic leukemia took the first place among acute leukemias $(44.4 \%$ or 8 cases); myeloid leukemia accounted for one third of all leukemia cases in children (33.3\% or 6 cases); a single monocytic leukemia case was diagnosed. A contribution made by leukemia of unspecified cell type was a bit different and accounted for $16.7 \%$ ( 3 cases) of all leukemia cases. A share that belonged to Hodgkin's disease among all $\mathrm{MN}$ in lymphoid and blood-making tissues was statistically insignificantly higher among children borne by parents who had been exposed to occupational preconception irradiation than among children whose parents hadn't been exposed to it (20.7\% against $17.3 \%, \mathrm{p}>0.05)$.

We should note that specific contribution made by all neoplasms in lymphoid tissues among children of irradiated parents didn't have any discrepancies from that among children whose parents were intact $(37.9 \%$ against $48.1 \%, \mathrm{p}>0.05)$. We compared contributions made by lymphoid leukemia and myeloid leukemia into oncohematological pathology structure among children born by exposed and nonexposed parents and didn't reveal any statistically significant discrepancies.

We didn't detect any gender differences in the structure of MN in lymphoid and bloodmaking tissues among children born by irradiated parents. Average age at which $\mathrm{MN}$ occurred among children born by exposed parents amounted to 14 years among boys and 8.2 years among girls.

Overall, we didn't detect any significant differences in the structure of child hemolymphoblastosis between national and world sta- 
tistical data and either children born by workers employed at nuclear production or total children population of Ozersk [13, 28].

Total doses of preconception external gamma-irradiation absorbed by parents at their workplaces varied significantly. Table 2 contains data on accumulated preconception irradiation doses.

Average total doses of preconception external gamma-irradiation absorbed by parents were higher in "Controls" group (children without oncologic pathology) than among exposed parents whose children were included into "Cases" group. However, maximum preconception dose of external gamma-irradiation on an overall body was detected among fathers of children with oncohematological pathologies and reached 3,397.3 mGy while a maximum dose among mothers amounted to 2,797.8 mGy and was detected in "Controls" group.

Average absorbed doses of preconception external gamma-irradiation on the gonads were higher among parents in "Controls" group than among parents in "Cases" group. Irradiation on the gonads varied within a substantial range, the highest accumulated dose being about 3 Gy; it was registered in parents from both groups as the maximum external gamma-irradiation dose on the gonads amounted to $3,121.8 \mathrm{mGy}$ in "Cases" group, and to 2,899.3 mGy, in "Controls" group.

Average preconception doses of external gamma-irradiation on the gonads were in some cases higher than doses on an overall body; on one hand, it can be due to uneven irradiation of Mayak PA personnel; on the other hand, quantity of individual doses on the gonads among workers was relatively insignificant, therefore, average values could be shifted.

Figure 2 shows how workers employed at Mayak PA are distributed as per accumulated preconception doses of external gamma-irradiation on an overall body.

Table 2

Preconception external gamma-irradiation accumulated by parents

\begin{tabular}{|l|c|c|c|c|}
\hline \multirow{2}{*}{$\begin{array}{c}\text { External gamma- } \\
\text { irradiation doses, mGy }\end{array}$} & \multicolumn{2}{c|}{ Exposed parents in "Cases" group } & Exposed parents in "Controls" group \\
\cline { 2 - 5 } & Fathers & Mothers & Fathers & Mothers \\
\hline \multicolumn{5}{|c|}{ External gamma-irradiation doses on an overall body } \\
\hline Average dose & $257.4 \pm 122.9^{*}$ & $244.3 \pm 206.1$ & $335.3 \pm 52.4$ & $458.1 \pm 129.6$ \\
\hline \multirow{2}{*}{ Median doses } & 50.1 & 42.1 & 62.9 & 125.5 \\
& $(19.5-177.6)^{* *}$ & $(20.7-84.8)$ & $(25.0-325)$ & $(24.9-731.2)$ \\
\hline Doses range & $2.7-3397.3$ & $2.06-1272.9$ & $0.3-3025.6$ & $2.13-2797.8$ \\
\hline \multicolumn{5}{|c|}{ External gamma-irradiation doses on gonads } \\
\hline Average dose & $338.5 \pm 188.3$ & $275.2 \pm 241.8$ & $411.6 \pm 70.4$ & $452.9 \pm 123.2$ \\
\hline \multirow{2}{*}{ Median doses } & 70.1 & 49.5 & 111.2 & 127.7 \\
\hline Doses range & $(37.9-210.2)$ & $(20.5-529.9)$ & $(31.2-337.7)$ & $(57.6-597.5)$ \\
\hline
\end{tabular}

* is standard deviation, ${ }^{* *}$ means an inter-quartile distance is given in brackets.

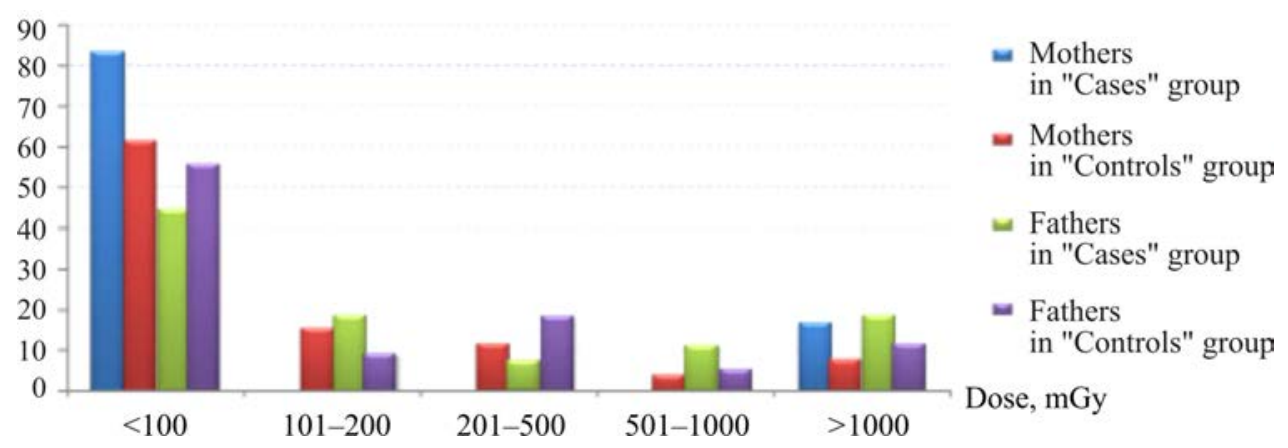

Figure 2. Distribution of Mayak PA workers as per total preconception doses of external gamma-irradiation on an overall body (\%) 
An accumulated dose didn't exceed 100 mGy among most irradiated parents. Preconception irradiation among mothers in "Cases" group had two end intervals, from 2.06 to 100 mGy and higher than 1,000 mGy. Mothers from "Controls" group were present in all dose categories. The smallest number of fathers in "Cases" group were exposed to preconception irradiation in a dose within 201-500 mGy range, while the minimal number of fathers in "Controls" group was detected in a dose category from 501 to $1,000 \mathrm{mGy}$. Total preconception doses of external gamma-irradiation on the gonads among Mayak PA workers were distributed in a similar way.

Most MN in lymphoid and blood-making tissues among children born by exposed parents were detected within a below $500 \mathrm{mGy}$ range of total preconception external gammairradiation doses received by parents on an overall body ( $79.3 \%$ or 23 cases). Acute leukemia was diagnosed among children born by parents exposed to a dose within 2.06-3,397.3 mGy range with an average dose on an overall body being equal to $312.8 \pm 170.8 \mathrm{mGy}$; on the gonads, $391.5 \pm 261.1 \mathrm{mGy}$. MN in lymphoid tissue were detected within 2.7-1,005.3 mGy doses range with an average external gamma-irradiation dose on an overall body being equal to $170.4 \pm 78.4 \mathrm{mGy}$; on the gonads, $233.7 \pm 105.5 \mathrm{mGy}$.
In order to reveal any statistical correlation between a risk factor (parents exposed to occupational preconception irradiation) and an outcome (hemolymphoblastosis in their children), we calculated odds ratio; the results are shown in Table 3.

OR in groups on general was equal to $0.76(0.46-1.26)$ and it proved there was no statistically significant correlation between parents being irradiated and oncohematological pathology in their children. OR amounted to $0.81(0.43-1.54)$ among boys, and to 0.69 (0.3-1.57) among girls, and it was also an evidence that there was no correlation between the examined risk factor (parents exposed to preconception irradiation) and a possible outcome in their children (hemolymphoblastosis).

To reveal whether carcinogenic risks in offspring were dose-dependent, we performed "dose - effect" analysis together with calculating excess relative risk of hemolymphoblastosis. The analysis covered total preconception irradiation doses received by parents on an overall body and separately on the gonads. The results are given in Table 4.

We applied a linear model to estimate ERR and didn't reveal any statistically significant increase in morbidity with hemolymphoblastosis depending on an irradiation dose received by parents. ERR/Gy quotients were insignificant in both cases among mothers

Table 3

Odds ratio calculation

\begin{tabular}{|l|c|c|c|c|c|c||c|c|c|}
\hline \multirow{2}{*}{ Group } & \multicolumn{3}{|c|}{ Risk factor occurs } & \multicolumn{2}{c|}{ Risk factor doesn't occur } & \multicolumn{3}{c|}{ OR (95\% CI) } \\
\cline { 2 - 9 } & Total & Boys & Girls & Total & Boys & Girls & Total & Boys & Girls \\
\hline $\begin{array}{l}\text { There is an } \\
\text { outcome (n=81) }\end{array}$ & 29 & 19 & 10 & 52 & 30 & 22 & $\begin{array}{c}0.76 \\
(0.46-1.26)\end{array}$ & $\begin{array}{c}0.81 \\
(0.43-1.54)\end{array}$ & $\begin{array}{c}0.69 \\
(0.3-1.57)\end{array}$ \\
\hline $\begin{array}{l}\text { There is no } \\
\text { outcome (n=324) }\end{array}$ & 137 & 86 & 51 & 187 & 110 & 77 & \\
\hline
\end{tabular}

Table 4

Excess relative risk (ERR) of hemoblastosis depending on preconception doses accumulated by parents

\begin{tabular}{|l|c|c|c|}
\hline \multicolumn{1}{|c|}{$\begin{array}{c}\text { Total preconception doses of external } \\
\text { gamma-irradiation accumulated by parents }\end{array}$} & ERR/Gy & $95 \%$ confidence interval & $p$ \\
\hline Fathers' doses on an overall body & -0.4015 & {$[-0.97 ; 0.14]$} & $>0.05$ \\
\hline Mothers' doses on an overall body & -0.0036 & {$[-1.08 ; 0.93]$} & $>0.05$ \\
\hline Fathers' doses on the gonads & -0.3148 & {$[-0.93 ; 0.26]$} & $>0.05$ \\
\hline Mothers' doses on the gonads & -0.2235 & {$[-1.57 ; 0.89]$} & $>0.05$ \\
\hline
\end{tabular}


and fathers employed at Mayak PA, either with an accumulated external gamma-irradiation dose on an overall body or separately on the gonads.

A.N. Koterov is being involved in a discussion on the genome instability being induced under small radiation doses and more frequent mutagenesis and carcinogenesis caused by them; he considers [29] different points of view expressed by several authors and notes results obtained via some experimental research when no instability in the genome was observed under exposure to doses smaller than 0.1-0.2 Gy but probable threshold for its induction amounted to 0.5 Gy with low linear energy transfer.

Analysis of our data taking into account dose categories with preconception doses intervals being equal to $250 \mathrm{mGy}$ didn't reveal any increase in carcinogenic risks as statistically insignificant negative ERR/Gy values were observed in the groups. At certain points, ERR value for hemolymphoblastosis associated with an external gamma-irradiation doses on the gonads was uncertain due to few available statistical data.

Therefore, our analysis didn't confirm an assumption that increased risks of $\mathrm{MN}$ in lymphoid and blood-making tissues could be somehow related to parents' exposure to preconception gamma-irradiation.

When accomplishing our research, we took into account impacts exerted by such nonradiation factors as sex, birth date, age of parents at the moment a child was born, and age at which $\mathrm{MN}$ was diagnosed. We should note that multiple factors have been described up to now that can cause oncogenic processes in lymphoid and blood-making tissues. Experts consider several factors that cause child hemolymphoblastosis, for example, infectious agents [30], preconception contact with chemical carcinogens [31], compromised obstetric history and $\mathrm{MN}$ occurrence in close relatives [27], deviations in perinatal period and anthropometric status peculiarities at birth [32], pre- and post-natal exposure to electromagnetic fields [33], and many other nonradiation factors that can't always be analyzed quantitatively [34]. Our task in the present research was to reveal a statistical correlation between a single probable risk factor, parents' occupational preconception irradiation, and neo- plastic hematologic processes in their offspring. Therefore, we didn't make any changes in our model in order to modify a dose response with various non-radiation factors.

The results we obtained are well in line with research $[35,36]$ that didn't reveal any statistically significant impacts via analyzing long-term effects produced by exposure to ionizing radiation.

Probably, estimation of a dose effect in our research was influenced by an initially insignificant statistical base as malignant neoplasms were relatively rare in children. But when an observation age for a cohort of children born by irradiated parents was increased up to 25 years [37], it didn't change any ultimate results in comparison with our previous research.

It is also important to note that parents who were exposed to preconception irradiation were employed at a nuclear production; workers were thoroughly selected to get a job there, including medical examinations, as they all should have very good health. Given that, irradiated parents could initially have greater health than parents from "Controls" group. Moreover, a rather small number of exposed parents in our sampling doesn't allow to be sure that there is no correlation between long-term exposure to ionizing irradiation before conception and malignant neoplasms occurrence in offspring.

So, we can assume that radiation-induced risk assessment depends on statistical significance of a group being examined; this, together with $\mathrm{MN}$ being a multi-factor disease, substantiates a necessity to continue research on effects produced on offspring by occupational preconception irradiation.

Conclusion. We analyzed risks of oncohematological pathology in children born by irradiated parents with "case - control in a cohort" method and individual estimates of external gamma-irradiation doses accumulated before a child was conceived. A cohort chosen for the research was made up of children born by parents employed at the first nuclear cycle enterprise in the country. We tested impacts exerted by parents' preconception irradiation on risks of hemoblastosis in their children via calculating odds ratio and assessing a dose-effect relationship. 
We included all cases of $\mathrm{MN}$ in lymphoid and blood-making tissues that occurred among children born in families of Mayak PA workers at an age up to 25 years, more than 90,000 people were observed during a 60 -year observation over children living in Ozersk; still, in spite all that, we couldn't detect any authentic increase in hemoblastosis risk among children born by parents who had been exposed to preconception irradiation at their workplaces.

We spotted out a single factor, preconception irradiation, among variable potential carcinogenic ones, and assessed it quantitatively; the assessment revealed there was no correlation between parents being exposed to irradiation and elevated MN risks in their children. Totally, OR amounted to 0.76 (0.46-1.26). ERR/Gy quotient, taking into account absorbed doses on an overall body, amounted to -0.4 [-0.97; 0.14] among fathers; -0.0036 [-1.08; 0.93], among mothers. ERR/Gy quotient, depending on an overall dose on the gonads received by fathers, amounted to $-0.31[-0.93$; $0.26]$; by mothers, -0.22 [-1.57; 0.89]. ERR analysis performed in dose categories with an interval equal to $250 \mathrm{mGy}$ didn't reveal any significant deviations from previous ERR calculations.

However, a relatively low number of $\mathrm{MN}$ in lymphoid and blood-making tissues imposes certain limitations on the validity of our conclusions; therefore, we can't state that a contact with ionizing irradiation at a workplace before conception is safe as regards carcinogenic risks for future children. Susceptibility to neoplasms in children and the effect manifestation as solid cancer at older ages can't be totally excluded and it is advisable to continue research on the subject.

Funding. The work has been accomplished with the State Contract No. 11.305.18.0 with its research subject being "Analysis of effects produced by exposure to ionizing radiation on health of personnel employed at Mayak PA and health of their children via assessing radiogenic risks".

Conflict of interests. The authors state there isn't any conflict of interests.

\section{References}

1. Bashlykova L.A. Nasledovanie tsitogeneticheskikh i molekulyarno-kletochnykh effektov v kletkakh kostnogo mozga zhivotnykh pri khronicheskom vozdeistvii ioniziruyushchego izlucheniya [Inheritance of cytogenetic and molecular cell effects in the bone marrow cells of animals with chronic exposure to ionizing radiation]. Izvestiya Samarskogo nauchnogo tsentra Rossiiskoi akademii nauk, 2017, vol. 19, no. 2-3, pp. 420-425 (in Russian).

2. Lomaeva M.G., Fomenko L.A., Vasil'eva G.V., Bezlepkin V.G. Tkanespetsificheskie izmeneniya urovnya polimorfizma prostykh povtorov v DNK potomkov raznogo pola, rozhdennykh ot obluchennykh samtsov ili samok myshei [Tissue-specific changes in the level of polymorphism of simple repeats in the DNA of descendants of different sex, born to irradiated male or female mice]. Radiatsionnaya biologiya. Radioekologiya, 2016, vol. 56, no. 2, 149 p. (in Russian).

3. Suman S., Kumar S., Moon B.H., Fornace A.J., Kallakury B., Datta K. Increased Transgenerational Intestinal Tumorigenesis in Offspring of Ionizing Radiation Exposed Parent APC1638N/+ Mice. Journal of Cancer, 2017, vol. 8, no. 10, pp. 1769-1773. DOI: 10.7150/jca.17803

4. Paris L., Giardullo P., Leonardi S., Tanno B., Meschini R., Cordelli E., Benassi B., Longobardi M.G. [et al.]. Transgenerational inheritance of enhanced susceptibility to radiation-induced medulloblastoma in newborn Ptch $1^{+} /$mice after paternal irradiation. Oncotarget, 2015, vol. 6, no. 34, pp. 36098-112. DOI: 10.18632/oncotarget.5553

5. Lord B.I., Hoyes K.P. Hemopoietic damage and induction of leukemia in offspring due to preconception paternal irradiation from incorporated plutonium-239. Radiation Research, 1999, vol. 152 (6 Suppl), pp. 34-37.

6. Suskov I.I., Kuz'mina N.S., Suskova V.S., Agadzhanyan A.V., Rubanovich A.V. Individual'nye osobennosti transgeneratsionnoi genomnoi nestabil'nosti u detei likvidatorov posledstvii avarii na ChAES (tsitogeneticheskie i immunogeneticheskie pokazateli) [Individual features of transgenerational genomic instability in children of the liquidators of the consequences of the Chernobyl accident (cytogenetic and immunogenetic indicators)]. Radiatsionnaya biologiya. Radioekologiya, 2008, vol. 48, no. 3, pp. 278-286 (in Russian).

7. Baleva L.S., Nomura T., Sipyagina A.E., Karakhan N.M., Yakusheva E.N., Egorova N.I. Tsitogeneticheskie effekty i vozmozhnosti ikh transgeneratsionnoi peredachi v pokoleniyakh lits, prozhivayushchikh 
$\mathrm{v}$ regionakh radionuklidnogo zagryazneniya posle avarii na Chernobyl'skoi AES [Cytogenetic effects and possibilities of their transgenerational transfer in the generations of persons living in radionuclide polluted areas after the Chernobyl accident]. Rossiiskii vestnik perinatologii $i$ pediatrii, 2016, vol. 3, pp. 87-94 (in Russian).

8. Rusinova G.G., Glazkova I.V., Azizova T.V., Osovets S.V., Vyazovskaya N.S. Izuchenie nestabil'nosti genoma potomkov v sem'yakh rabotnikov PO «Mayak»: minisatellit SEV 1 [Analysis of Genome Instability in Offspring of "Mayak" Workers Families: Minisatellite CEB1]. Genetika, 2014, vol. 50, no. 11, pp. 1354-1362 (in Russian).

9. Apsalikov K.N., Muldagaliev T.Zh., Belikhina T.I., Tanatova Z.A., Kenzhina L.B. Analiz i retrospektivnaya otsenka rezul'tatov tsitogeneticheskikh obsledovanii naseleniya Kazakhstana, podvergavshegosya radiatsionnomu vozdeistviyu v rezul'tate ispytanii yadernogo oruzhiya na Semipalatinskom poligone, i ikh potomkov [Analysis and retrospective assessment of the results of cytogenetic surveys of the population of Kazakhstan exposed to radiation as a result of nuclear weapon tests at the Semipalatinsk test site, and their descendants]. Mediko-biologicheskie problemy zhiznedeyatel'nosti, 2013, vol. 9, no. 1, pp. 42-49 (in Russian).

10. Sources, effects and risks of ionizing radiation: UNSCEAR Report. Effects of radiation exposure of children. UNITED NATIONS, New York. 2013, vol. II, $282 \mathrm{p}$.

11. Little M.P., Goodhead D.T., Bridges B.A., Bouffler S.D. Evidence relevant to untargeted and transgenerational effects in the offspring of irradiated parents. Mutation Research, 2013, vol. 753, no. 1, pp. 50-67. DOI: 10.1016/j.mrrev.2013.04.001

12. Puumala S.E., Ross J.A., Aplenc R., Spector L.G. Epidemiology of childhood acute myeloid leukemia. Pediatric Blood and Cancer, 2013, vol. 60, no. 5, pp. 728-733.

13. Metayer C., Milne E., Clavel J., Infante-Rivard C., Petridou E., Taylor M., Schüz J., Spector L.G. [et al.]. The Childhood Leukemia International Consortium. Cancer Epidemiology, 2013, vol. 37, no. 3, pp. 336-347.

14. Gardner M.J., Snee M.P., Hall A.J., Powell C.A., Downes S., Terrell J. D. Results of casecontrol study of leukaemia and lymphoma among young people near Sellafield nuclear plant in West Cumbria. British Medical Journal, 1990, vol. 300, pp. 423-429.

15. McLaughlin J.R., King W.D., Anderson T.W., Clarke E.A., Ashmore J.P. Paternal radiation exposure and leukaemia in offspring: the Ontario case-control study. British Medical Journal, 1993, vol. 307, no. 6910, pp. 959-966.

16. Kinlen L.J, Clarke K., Balkwill A. Paternal preconceptional radiation exposure in the nuclear industry and leukaemia and non-Hodgkin's lymphoma in young people in Scotland. British Medical Journal, 1993, vol. 306, no. 6886, pp. 1153-1158.

17. Draper G.J, Little M.P., Sorahan T., Kinlen L.J, Bunch K.J., Conquest A.J., Kendall G.M., Kneale G.W. [et al.]. Cancer in the offspring of radiation workers: a record linkage study. British Medical Journal, 1997, vol. 315, no. 7117, pp. 1181-1188.

18. Roman E., Doyle P., Maconochie N., Davies G., Smith P.G., Beral V. Cancer in children of nuclear industry employees: report on children aged under 25 years from nuclear industry family study. British Medical Journal, 1999, vol. 318, no. 7196, pp. 1443-1450.

19. Kamiya K., Ozasa K., Akiba S., Niwa O., Kodama K., Takamura N., Zaharieva E.K., Kimura Y. [et al.]. Long-term effects of radiation exposure on health. Lancet, 2015, vol. 386, no. 9992, pp. 469-78. DOI: $10.1016 / \mathrm{S} 0140-6736(15) 61167-9$

20. Grant E.J., Furukawa K., Sakata R., Sugiyama H., Sadakane A., Takahashi I., Utada M., Shimizu Y. [et al.]. Risk of death among children of atomic bomb survivors after 62 years of follow-up: a cohort study. Lancet Oncology, 2015, vol. 16, no. 13, pp. 1316-1323. DOI: 10.1016/S1470-2045(15)00209-0

21. Wakeford R. Childhood leukaemia and radiation exposure of fathers - the end of the road, perhaps? Journal of Radiological Protection, 2003, vol. 23, no. 4, pp. 359-362.

22. Vasilenko E.K. Dozimetriya vneshnego oblucheniya rabotnikov PO «Mayak»: pribory, metody, rezul'taty [Dosimetry of external radiation in PA "Mayak" workers: instruments, methods, results]. Istochniki i effekty oblucheniya rabotnikov $\mathrm{PO}$ «Mayak» i naseleniya, prozhivayushchego v zone vliyaniya predpriyatiya [The sources and the effects of exposure of PA "Mayak" workers and the population living in the zone of the enterprise influence]. In: M.F. Kiselev, S.A. Romanov, ed. Chelyabinsk, Chelyabinskii dom pechati Publ., 2009, Part 1, pp. 51-100 (in Russian).

23. Khokhryakov V.V., Khokhryakov V.F., Suslova K.G., Vostrotin V.V., Vvedensky V.E., Sokolova A.B., Krahenbuhl M.P., Birchall A. [et al.]. Mayak Worker Dosimetry System 2008 (MWDS-2008): 
assessment of internal dose from measurement results of plutonium activity in urine. Health Physics, 2013, vol. 104, no. 4, pp. 366-378.

24. Statisticheskaya klassifikatsiya boleznei, travm i prichin smerti (adaptirovannyi variant MKB-9 dlya ispol'zovaniya v SSSR). Izdanie 2-e. [Statistical classification of diseases, injuries and causes of death (adapted version of the ICD-9 for use in the USSR). Edition 2, Moscow, 1986, 97 p. (in Russian).

25. Mezhdunarodnaya statisticheskaya klassifikatsiya boleznei i problem, svyazannykh so zdorov'em. Desyatyi peresmotr, tom 1 (chast' 2) [International Statistical Classification of Diseases and Related Health Problems, Tenth Revision, vol. 1]. Moscow: Meditsina Publ., 1995, 633 p. (in Russian).

26. Preston D.L., Lubin J.H., Pierce D.A. McConney M. EPICURE user's Guide. Seattle, Hirosoft International Corporation Publ., 1993, 330 p.

27. Zhukovskaya E.V., Spichak I.I., Basharova E.V., Volosnikov D.K., Kovalenko S.G., Ogoshkova I.A. Zabolevaemost' ostrymi leikozami i ikh rasprostranennost' $\mathrm{v}$ detskoi populyatsii Chelyabinskoi oblasti za period 1974-2003 gg. [The incidence of acute leukemia and their prevalence in the children's population of the Chelyabinsk region for the period 1974-2003]. Voprosy gematologii/onkologii i immunopatologii v pediatrii, 2005, vol. 4, no. 1, pp. 20-24 (in Russian).

28. Men' T.Kh., Rykov M.Iu., Poliakov V.G. Zlokachestvennye novoobrazovaniya u detei v Rossii: osnovnye pokazateli i tendentsii [Malignant neoplasms in children in Russia: main indicators and trends]. Rossiiskii onkologicheskii zhurnal, 2015, vol. 20, no. 2, pp. 43-47 (in Russian).

29. Koterov A.N. Novye fakty ob otsutstvii induktsii nestabil'nosti genoma pri malykh dozakh radiatsii s nizkoi LPE i sootvetstvuyushchie vyvody o poroge effekta v soobshchenii NKDAR-2012 [New facts about the absence of induction of genome instability at low doses of radiation with low LET and the corresponding conclusions about the threshold effect in the message UNSCEAR - 2012]. Radiatsionnaya biologiya. Radioekologiya, 2014, vol. 54, no. 3, pp. 309-312 (in Russian).

30. Hwee J., Tait C., Sung L., Kwong J.C., Sutradhar R., Pole J.D. A systematic review and metaanalysis of the association between childhood infections and the risk of childhood acute lymphoblastic leukaemia. British Journal of Cancer, 2018, vol. 118, no. 1, pp. 127-137. DOI: 10.1038/bjc.2017.360

31. Miligi L., Benvenuti A., Mattioli S., Salvan A., Tozzi G.A., Ranucci A., Legittimo P., Rondelli R. [et al.]. Risk of childhood leukaemia and non-Hodgkin's lymphoma after parental occupational exposure to solvents and other agents: the SETIL Study. Occupational and Environmental Medicine, 2013, vol. 70, no. 9, pp. 648-655. DOI: 10.1136/oemed-2012-100951

32. Crump C., Sundquist J., Sieh W., Winkleby M.A., Sundquist K. Perinatal and familial risk factors for acute lymphoblastic leukemia in a Swedish national cohort. Cancer, 2015, vol. 121, no. 7, pp. 1040-1047.

33. Tabrizi M.M., Hosseini S.A. Role of Electromagnetic Field Exposure in Childhood Acute Lymphoblastic Leukemia and No Impact of Urinary Alpha- Amylase - a Case Control Study in Tehran, Iran. Asian Pacific Journal of Cancer Prevention, 2015, vol. 16, no. 17, pp. 7613-7618.

34. Magnani C., Mattioli S., Miligi L., Ranucci A., Rondelli R., Salvan A., Bisanti L., Masera G. [et al.]. SETIL: Italian multicentric epidemiological case-control study on risk factors for childhood leukaemia, non hodgkin lymphoma and neuroblastoma: study population and prevalence of risk factors in Italy. Italian Journal of Pediatrics, 2014, vol. 40, 103 p. DOI: 10.1186/s13052-014-0103-5

35. Draper G. Preconception exposures to potential germ-cell mutagens. Radiation Protection Dosimetry, 2008, vol. 132, no. 2, pp. 241-245.

36. Johnson K.J., Alexander B.H., Doody M.M., Sigurdson A.J., Linet M.S., Spector L.G., Hoffbeck W., Simon S.L. [et al.]. Childhood cancer in the offspring born in 1921-1984 to US radiologic technologists. British Journal of Cancer, 2008, vol. 99, no. 3, pp. 545-550.

37. Sosnina S.F., Kabirova N.R., Sokolnikov M.E., Okatenko P.V. Gemoblastozy u potomkov rabotnikov radiatsionno opasnykh proizvodstv [Hemoblastoses in offspring of radiationhazardous industries workers]. Analiz riska zdorov'yu, 2016, no. 4, pp. 23-30. DOI: 10.21668/health.risk/2016.4.03.eng (in Russian).

Sosnina S.F., Kabirova N.R., Sokolnikov M.E., Okatenko P.V. The risk of oncohematological pathology in children of workers employed at radiation-hazardous production. Health Risk Analysis, 2019, no. 1, pp. 30-39. DOI: 10.21668/health.risk/2019.1.03.eng

Received: 09.10.2018

Accepted: 19.01.2019

Published: 30.03.2019 